\title{
Defining and Measuring A2K: A Blueprint for an Index of Access to Knowledge
}

\section{LEA BISHOP SHAVER*}

Abstract: Access to knowledge (A2K) is increasingly recognized as the central human development issue of our time. Yet to date there has been little literature defining precisely what is meant by this term, much less how to evaluate the progress toward achieving it. To help bridge this gap, this article offers a blueprint for an A2K index: a quantitative tool integrating a variety of data points to assess how well countries promote access to knowledge. The proposed index tracks five key dimensions of access to knowledge: education for informational literacy, access to the global knowledge commons, access to knowledge goods, an enabling legal framework, and effective innovation systems. The resulting conceptual map offers a concrete introduction to the A2K framework for information scholars and professionals.

\footnotetext{
"The author and publisher grant permission for copies of this article to be made for library or classroom use or for any other educational purposes, provided that (1) copies are distributed at or below cost, and (2) the author and I/S Journal are identified. A digital copy may be downloaded from: http://ssrn.com/abstract=1021065 and www.isjournal.org. The author also wishes to acknowledge the Information Society Project at Yale Law School and the John D. and Catherine T. MacArthur Foundation for their support of this research.
} 
"I often say that when you can measure what you are speaking about, and express it in numbers, you know something about it; but when you cannot measure it, when you cannot express it in numbers, your knowledge is of a meagre and unsatisfactory kind ...."

"If you cannot measure it, you cannot improve it."

-Lord Kelvin ${ }^{1}$

\section{INTRODUCTION}

Access to knowledge (A2K) is increasingly recognized as the central human development issue of our time. Within the past decade, both the World Bank and the United Nations Development Programme (UNDP) have issued major global reports focused on the themes of knowledge and technology for development. ${ }^{2}$ The United Nations Educational, Scientific and Cultural Organization (UNESCO) also adopted the theme of the knowledge society as the focus of its first-and, to date, only-world report. ${ }^{3}$ Meanwhile, a global civil society movement has emerged around a Draft Treaty on Access to Knowledge, in tandem with the successful push for a new "development agenda" within the World Intellectual Property Organization. 4

\footnotetext{
1 William ThOMSON Kelvin, BARON, POPULAR LECTURES AND ADDRESSES 80 (London, MacMillan 1883), available at http://www.google.com/books/pdf/Popular_Lectures and_Addresses.pdf?id=JcMKAAAAIAAJ\&output $=$ pdf\&sig $=U_{7}$ Wc9jZNYkxaB7JEmmfQeN IimSw\&source=gbs_summary_r. The First Baron Kelvin (1824-1907) was the originator of the Kelvin absolute temperature scale.

2 U.N. DEV. PRogramme, HuMAN DEVELOPMENT REPORT 2001: MAKING NEW TECHNOLOGIES WORK FOR HUMAN DEVELOPMENT (2001), http://hdr.undp.org/en/ media/completenew1.pdf; WORLD BANK, WORLD DEVELOPMENT REPORT 1998/99: KNOWLEDGE FOR DEVELOPMENT (1999), http://www.worldbank.org/wdr/ wdr98/overview.pdf.
}

3 UNESCO, TOWARDS KNOWLEDGE SOCIETIES (2005), http://unesdoc.unesco.org/ images/o014/o01418/141843e.pdf.

4 Treaty on Access to Knowledge (draft), May 9, 2005, http://www.cptech.org/a2k/ a2k_treaty_may9.pdf; Proposal by Argentina and Brazil for the Establishment of a Development Agenda for WIPO, WO/GA/31/11, August 27, 2004, endorsed by WIPO General Assembly October 4, 2004, http://www.wsis-pct.org/WIPO/devel-agenda27augo5.html. 
Yet, even as more and more civil society organizations and policymakers embrace the access to knowledge agenda, many remain unsure exactly how the A2K concept translates into practice. To date, there has been little literature defining precisely what is meant by the term "access to knowledge," much less indicating how to evaluate a nation's progress toward achieving this goal.5 Quantitative measures to guide policymaking, such as those developed for other areas of public policy, are lacking in the field of A2K. ${ }^{6}$ As a result, citizens and policymakers have no way of knowing how well their nations "stack up" to their peers in promoting and facilitating access to knowledge. In addition, social scientists wishing to test hypotheses about the determinants and benefits of improved access to knowledge have no data set upon which to draw.

To bridge this gap, the time has come for an A2K index: a quantitative tool integrating a variety of data points to assess how well countries promote access to knowledge. In this article, I offer a blueprint for a robust and reliable Index of Access to Knowledge. This index builds on a conceptual framework that identifies five key dimensions of access to knowledge: education for information literacy, access to the global knowledge commons, access to knowledge goods,

\footnotetext{
5 Existing published work has been largely qualitative in nature, with an emphasis on descriptive case studies. The 2005 UNESCO World Report, for instance, offers a comprehensive overview of access to knowledge themes including communications technologies, education, scientific research, indigenous knowledge, linguistic diversity, and gender gaps in knowledge access and participation. However, the report is overwhelmingly qualitative in method, with only a handful of quantitative tables and graphs between nearly 200 pages of descriptive accounts and policy recommendations. See UNESCO, supra note 3. The Information Society Project at Yale Law School is currently developing a multivolume series on Access to Knowledge in cross-national perspective, which also adopts a primarily qualitative approach to $\mathrm{A} 2 \mathrm{~K}$ research. These forthcoming publications will be made available at http://isp.law.yale.edu.

6 The tool in widest use is the Human Development Index, which the United Nations Development Programme introduced in 1990 and has updated in each annual Human Development Report. See UNDP, HUMAN DEVELOPMENT REPORT 1990: CONCEPT AND MEASUREMENT OF HUMAN DEVELOPMENT (1990), http://hdr.undp.org/en/media/ hdr_1990_en.pdf. Other popular indexing tools include the Environmental Sustainability Index, the Corruption Perceptions Index, and the Freedom in the World Index. YALE CTR. FOR ENVTL LAW AND POL'Y \& THE CTR. FOR INT'L EARTH SCI. INFO. NETWORK OF COLUMBIA UNIV., 2008 ENVIRONMENTAL PERFORMANCE INDEX (2008), http://sedac.ciesin.columbia.edu/es/epi/index.html; TRANSPARENCY INTERNATIONAL, CORRUPTION PERCEPTIONS INDEX 2007 (2007), http://www.transparency.org/ policy_research/surveys_indices/cpi/2007; FREEDOM HOUSE, FREEDOM IN THE WORLD: 2007 EDITION (2008), http://www.freedomhouse.org/template.cfm? page $=3638$ year $=2007$.
} 
an enabling legal framework, and effective innovation systems. Within each component, I explore the factors that impact access to knowledge and identify appropriate indicators. Where desired data is not yet readily available, the gap is highlighted as presenting an opportunity for future research.

The resulting conceptual framework for Access to Knowledge is useful to a variety of audiences. For policymakers, development practitioners, and information professionals not already familiar with the A2K framework, the outlined index provides an accessible point of entry. For academics and activists already part of the access to knowledge community, this proposal also serves as a challenge to critique and improve upon the theoretical framework of A2K as I have defined it. Finally, because some elements of the proposed index will require extensive research to fully develop, this article should also be understood as an outline of an A2K research agenda for the next decade.

\section{A CONCEPTUAL FRAMEWORK FOR A2K}

As the opening quotes from Lord Kelvin highlight, efforts to measure and monitor A2K can facilitate governments' ability to promote access to knowledge, but also require researchers to answer hard conceptual and empirical questions about this subject. "Access to knowledge" remains a young concept, and there is currently no single authoritative explanation of what the term encompasses. Legal scholars Madhavi Sunder and Amy Kapczynski have analyzed A2K from a social movement perspective, emphasizing the centrality of intellectual property rules in determining access.7 In contrast, Yochai Benkler, writing on the transformative economic and social potential of collaborative production, locates intellectual property rules as just one point within a broader set of issues affecting openness in the information environment. ${ }^{8}$ I advocate a framework for A2K that follows this broader view, recognizing that access to knowledge is

\footnotetext{
7 See Madhavi Sunder, IP3, 59 STAN. L. REv. 257 (2006), available at http://papers.ssm.com/sol3/papers.cfm?abstract_id=897753; Amy Kapczynski, The Emerging Access to Knowledge Movement and the New Politics of Intellectual Property Law, YALE L.J. (forthcoming).

${ }^{8}$ See Yochai Benkler, The Wealth of Networks: How SOCIAl Production TRANSFORMS MARKETS AND FREEDOM (2006), available at http://www.jus.uio.no/ sisu/the_wealth_of_networks.yochai_benkler/portrait.pdf. See also, Posting of Jack Balkin to Balkanization Blog, http://balkin.blogspot.com/2006/04/what-is-access-toknowledge.html (Apr. 21, 2006, 19:05 EST).
} 
shaped by a variety of factors, including but not limited to: access to education, support for innovation, technological diffusion, freedom of expression, and intellectual property regulation.

This theory of access to knowledge is grounded in the capabilities tradition of development economics. First articulated by Indian economist Amartya Sen in 1985, the capabilities approach defines the end goal of economic development as assuring that all human beings enjoy certain important capabilities-such as the ability to live a long and healthy life, to be literate and numerate, and to enjoy political participation and freedoms. 9 This perspective, which became known as "human development," departed from traditional development economics by advocating a focus on measures of success beyond national competitiveness and gross domestic product, to place the emphasis on human welfare and quality of life. The United Nations Development Programme has since popularized this approach, in part through the construction and annual updates of its human development index (HDI), which tracks indicators of health, education, and poverty.

Building on this tradition, the A2K perspective focuses on one particular capability: the ability to access, utilize, and contribute to knowledge. ${ }^{10}$ Like the many capabilities more traditionally associated with the human development paradigm, access to knowledge is considered a universal good-although different cultures and individuals may value different types of knowledge and wish to access, utilize, and contribute to it in different ways. In the terminology of

\footnotetext{
9 See AMARTYA K. SEN, COMMODITIES AND CAPABILITIES (1985); AMARTYA KUMAR SEN, DEVELOPMENT AS FREEDOM (1999), available at http://books.google.com/

books?id=Qm8HtpFHYecC. Sen's work in bringing this ethical dimension to economics resulted in a Nobel Prize in 1998 . The capabilities approach was also strongly formed by the work of U.S. moral philosopher Martha Nussbaum. See generally THE QUALITY OF LIFE (Martha C. Nussbaum \& Amartya Sen eds., 1993), available at http://books.google.com/ books?id=pJaz1471B68C; MARTHA C. NUSSBAUM, WOMEN AND HUMAN DEVELOPMENT: THE CAPABILITIES APPROACH (2000), available at http://books.google.com/books?id=9R69I-rpzUC.
}

10 I have deliberately avoided attempting to define "knowledge." The term has many potential dimensions of meaning, most of which have some relevance to the A2K paradigm. For a useful terminological archetype of knowledge as it relates to A2K, see BENKLER, supra note 8, at ch. 9 (defining a four-part conceptual categorization: knowledge, information, information-embedded tools, and information-embedded goods). Nevertheless, there may be certain categories of knowledge that should not be universally accessible: for example, intimate information that implicates privacy concerns. See generally Daniel J. Solove, "I've Got Nothing to Hide" and Other Misunderstandings of Privacy, 44 SAN DIEGO L. REV. 745 (2007), available at http://ssrn.com/abstract=998565. 
moral philosopher John Rawls, access to knowledge would be considered a "primary good"-valuable, or at least not harmful- to everyone, regardless of their particular lifestyle preferences or moral viewpoint." ${ }^{11}$ The A2K perspective emphasizes access to knowledge as a human capability of central importance, because knowledge is a resource of unique importance to human welfare.

Princeton historian Joel Mokyr has best illustrated the strong causal relationship between the spread of useful knowledge and improvements in standards of living. ${ }^{12}$ Mokyr identifies the rationalization and diffusion of knowledge that accompanied the Enlightenment as a direct enabler of the Industrial Revolution. During this era, widespread improvements in both the stock of knowledge about the world and the ease of accessing that knowledge enabled rapid technological innovation and diffusion. The spread of knowledge in the areas of agriculture, industry, and medicine led to higher productivity and rising living standards. According to Mokyr's theory, the relative ease or difficulty of gaining access to existing knowledge determines how quickly improvements in knowledge translate into the adoption of superior techniques and rising human welfare. As Benkler points out, because existing knowledge is also an input to the production of new knowledge, access costs also strongly impact the rate of future innovation. ${ }^{13}$ The A2K perspective's concern with "access" is thus central to the overall efficiency of knowledge, innovation, and diffusion. ${ }^{14}$

The emphasis on "access" is equally motivated by a concern for equity: an ethical commitment to the proposition that the world's poor and vulnerable populations should not be excluded from sharing in the benefits of advances in human knowledge. When knowledge is

\footnotetext{
11 See generally JOHN RAWLS, A THEORY OF JUSTICE (Belknap Press 1999) (1971), available at http://books.google.com/books?id=b7GZr5Btp3oC. See also JAN A. G. M. vAN DIJK, THE DEEPENING DIVIDE: INEQUALITY IN THE INFORMATION SOCIETY 135 (2005), available at http://books.google.com/books?id=idWNYimCP1MC (arguing that information constitutes a primary good within the Rawlsian paradigm).
}

12 JOEL MOKYR, THE GIFTS OF ATHENA: HISTORICAL ORIGINS OF THE KNOWLEDGE ECONOMY 28-29 (2002), available at http://books.google.com/books?id=alOdfmgXaEoC.

${ }_{13}$ See BENKLER, supra note 8, at 35-58.

14 Moreover, unlike land or labor or other limited resources, knowledge is a "nonrival" good-its use for one person for one purpose does not preclude its use by another person for another purpose. See generally BENKLER, supra note 8. Knowledge-based development therefore offers the prospect of continuous and accelerating improvements in quality of life, drawing increasing value from an unlimited and expanding resource. 
difficult to access-whether due to poor infrastructure, high prices, malfunctioning markets, legal restrictions, or lack of human capitalit is the world's poor that will disproportionately suffer from the inability to translate existing knowledge into improved welfare. If the existing knowledge ecosystem works relatively well for wealthy individuals in the most developed countries, it is greatly under-serving poor individuals in the least developed countries, who often do not have access to essential medicines, learning materials, or communications technologies. It is a limited moral victory for humanity when useful knowledge is discovered and produced somewhere in the world, if the majority of the world's population is unable to utilize it.

The A2K perspective's treatment of knowledge as a primary good-and its central emphasis on issues of accessibility for both efficiency and equity-distinguish it from the more traditional "knowledge for development" (K4D) paradigm. This approach was pioneered by the World Bank, which has introduced two indices-the Knowledge Index (KI) and Knowledge Economy Index (KEI)-to track countries' success in "building knowledge economies." 15 The Bank's indices focus on the role of knowledge in development and offer a helpful starting point for designing an A2K index. However, the World Bank's approach is not grounded in an access to knowledge perspective. A number of factors considered central to A2K are not represented in the Bank's indices, such as a nation's respect for freedom of expression, and issues of equity in access to technology. Indeed, some features of the Bank's indices are highly problematic from the A2K perspective, such as the use of patent application rates as an indicator of innovation. ${ }^{16}$

At bottom, these critiques stem from a fundamental difference between the World Bank's interest in the "knowledge economy" and the A2K project. The Bank's knowledge economy approach is fundamentally concerned with harnessing the profit potential of knowledge to drive national competitiveness and GDP growth. In contrast, the $\mathrm{A} 2 \mathrm{~K}$ perspective recognizes that the innovation and

\footnotetext{
15 See generally WORLD BANK, BUILDING KNOWLEDGE ECONOMIES: ADVANCED STRATEGIES FOR DEVELOPMENT (2007), http://books.google.com/books?id=cZyvZXoJCfAC; DEREK H.C. CHEN \& CARL J. Dahlman, THE KNOWLEDGE ECONOMY, THE KAM METHODOlOGY, AND WORLD BANK OPERATIONS (2005), http://siteresources.worldbank.org/KFDLP/Resources/ KAM_Paper_WP.pdf. For a detailed explanation of the World Bank's knowledge indices and current rankings, see World Bank, KEI and KI Indexes, http://info.worldbank.org/ etools/kam2/KAM_page5.asp (last visited Apr. 4, 2008).

${ }^{16}$ See infra notes 5244-66 and accompanying text.
} 
diffusion of knowledge contribute to human welfare in a number of ways, not simply through the sale of more and higher-value goods on world markets. Quality of life may be improved by expanding people's ability to access, utilize, and contribute to knowledge in ways that may not have direct profit potential-such as solving social problems neglected by the market, promoting and defending political and cultural freedom, and expressing human values through discovery and communication.

With these theoretical underpinnings in mind, the remainder of this article sets forth a proposed framework for an A2K index. The index I propose is separated into five categories representing key dimensions of access to knowledge: (1) education for information literacy, (2) access to the global knowledge commons, (3) access to knowledge goods, (4) an enabling legal framework, and (5) effective innovation systems. Within each category, I identify several potential indicators that the index could draw upon, with a discussion of their relative strengths and weaknesses.

\section{EDUCATION FOR INFORMATIONAL LITERACY}

The first aspect of access to knowledge to be measured is education for informational literacy. Informational literacy represents the ease with which an individual is able to locate, understand, apply, and communicate stored information; in short, it is the ability to be a sophisticated consumer and producer of knowledge. As the name suggests, the ability to read and write is an important component. Informational literacy, however, is much more than the sum of these two very basic skills. An individual's ability to be a proficient and sophisticated consumer and producer of knowledge depends on broader educational factors such as the degree of technical training they have attained, their skills in critical thinking, and the languages they are fluent in, among others. ${ }^{17}$

To illustrate this principle, imagine a person who cannot read, nor operate simple communications technology such as a radio or telephone, and who lacks the critical thinking skills to separate reliable sources from dubious ones. Like a young child, this person

\footnotetext{
${ }_{17}$ There are, of course, exceptions to the general rule that an individual must be information literate to access knowledge. Many knowledge-embedded goods transfer the benefits of knowledge, without any intellectual effort on the part of the consumer. For instance, an infant enjoys access to the fruits of scientific knowledge when he or she receives a vaccine, without needing to understand the principles of medicine. Access to knowledge-embedded goods as one component of A2K is addressed in Section I, infra.
} 
depends on face-to-face verbal communication to meet all their knowledge needs, and relies on simple luck to access a knowledgeable and honest informer. At the other end of the scale, imagine a technologically-savvy, university-educated individual who is fluent in both English and Chinese. This person is able to access a large amount of sophisticated information from multiple sources, digest it with ease, and synthesize it into a bilingual report for redistribution over the Internet. These two individuals enjoy vastly different levels of access to knowledge-both as consumers and producers-as a result of their differing sets of information skills.

Informational literacy represents the human capital necessary to benefit from existing knowledge and to contribute to its increase. As with other types of human capital, the benefits of informational literacy may accrue not only to the particular individual possessing these skills, but also to other members of their society. For example, a very young child may not be able to directly consume complex information about nutrition, agriculture, or education, but she can benefit greatly if her parents, teachers, and community members are empowered to locate, understand, and apply that knowledge.

\section{A. INFORMATIONAL LITERACY}

It is simple enough to define informational literacy as the ability to effectively locate, understand, apply, and communicate stored information. But how can it be measured for the purposes of an A2K index? Since informational literacy is a skill developed by individuals, some form of individual testing may be appropriate.

Several institutions have worked to develop standards for assessing informational literacy. ${ }^{18}$ So far, however, no organization

\footnotetext{
${ }^{18}$ As early as 1998, the American Association of School Libraries (AASL) and the Association for Educational Communication and Technology (AECT) adopted informational literacy standards appropriate to the primary and secondary grades. See AASL \& AECT, INFORMATION LITERACY STANDARDS FOR STUDENT LEARNING (1998), http://www.ala.org/ala/aasl/aaslproftools/informationpower/InformationLiteracyStandar ds_final.pdf. The Association of College and Research Libraries (ACRL) has adopted a related set of standards geared to students in higher education. See ACRL, INFORMATION LITERACY COMPETENCY STANDARDS FOR HIGHER EDUCATION, (2000), http://www.ala.org/ ala/acrl/acrlstandards/standards.pdf. See also TERESA Y. NEELY, INFORMATION LITERACY ASSESSMENT: STANDARDS-BASED TOOLS AND ASSIGNMENTS (2006), available at http://books.google.com/books?id=RfwbGdBKrVEC. Several U.S. states have developed more specific outcome-based standards for assessing informational literacy among schoolchildren. Among these, Alaska's Library/Information Literacy Standards offers a robust and concise framework of the specific skills that should be measured as part of any information literacy assessment. See Alaska Association of School Libraries, Student Content Standards for School Libraries, http://www.akla.org/akasl/lib/
} 
has translated these guidelines into a standardized assessment tool for measuring informational literacy. A new testing approach developed by the Educational Testing Service (ETS), however, offers a model for how such an assessment might be designed. The ETS recently introduced a computer-based testing method to evaluate information and communications technology (ICT) literacy called "iSkills." 19 The iSkills exam challenges test-takers to perform specified tasks involving information retrieval, analysis, and communication using basic office software such as e-mail and slideshow applications. For example, one iSkills scenario challenges test-takers to translate an e-mail discussion of persuasive arguments into an overhead slide. The testing software assigns a numeric score based on the test-taker's proficiency in completing the tasks.

Although the iSkills exam is designed to measure ICT literacy, its task-based assessment approach offers an interesting model on which to design an informational literacy exam. The relevant skills that might be tested by such an exam could include: locating relevant materials, evaluating the reliability of different information sources, summarizing content in one's own words, and answering comprehension questions. Because this methodology relies on direct testing, however, the research costs incurred in administering the exam to a representative sample at regular intervals would be prohibitive for most countries.

A less expensive alternative would be to use an oral interview that tests relevant knowledge as a proxy for the ability to actually perform the tasks. Recent research on digital literacy suggests that asking people to rate their own skills is quite inaccurate; the responses more closely measure a person's digital confidence than their digital aptitude. The same research suggests, however, that quizzing people on their familiarity with specific terms-such as Advanced Search, MP3, Preference Settings, and Newsgroups-yields a much better

studentstandards.html (last visited Mar. 19, 2008). For much greater detail, compare with Ohio's K-12 Academic Content Standards in Technology, http://www.ode.state.oh.us/ GD/Templates/Pages/ODE/ODEPrimary.aspx?Page=2\&TopicID=305\&TopicRelationID= 339 (last visited Apr. 4. 2008). More examples can be found at Florida International University Libraries' list of Information Competencies, Standards and Outcomes, http://www.fiu.edu/ library/ili/ iliweb.html\# competencies (last visited Apr. 4, 2008).

19 For more detail on the iSkills assessment of information and communications technology literacy, see the online iSkills tour or the iSkills slideshow presentation. ETS, iSkills Tour, http://www.ets.org/Media/Products/ICT_Literacy/demo2/ (last visited Apr. 4, 2008); ETS, iSkills Slideshow Presentation, http://www.ets.org/Media/Tests/ICT_Literacy/pdf/ALA-062605.ppt (last visited Apr. 4, 2008) (prepared for the 2005 national conference of the American Library Association). 
proxy for actual digital literacy. ${ }^{20}$ Following this insight, once an acceptable performance-based assessment of informational literacy is developed, additional research can identify robust proxy measures, which could be assessed through a short questionnaire.

\section{B. EDUCATIONAL ATTAINMENT}

As the discussion above makes clear, developing an appropriate informational literacy assessment will require a great deal of further research. Until direct measures are developed, the A2K index should rely on educational attainment as a proxy for informational literacy. This approach assumes that a person's level of educational attainment is strongly correlated with their ability to locate, understand, apply, and communicate stored knowledge. This assumption seems reasonable enough in the abstract, but has some important limitations in practice. Completion statistics alone cannot reveal how effectively a society's education system prepares learners to participate as active knowledge consumers and producers. Two students completing ten years' education in Austria and Afghanistan, respectively, are not likely to demonstrate comparable information skills. Educational attainment should thus be viewed as only a very rough proxy for informational literacy until better measures are developed.

Assuming that educational attainment belongs in the A2K index, which education indicators should be used? International statistics on education commonly emphasize two indicators: primary enrollment rates and basic literacy. ${ }^{21}$ The choice of these two indicators focuses attention on extending basic educational opportunities to the least advantaged members of society. This emphasis is not appropriate for the A2K index, however, because the extremely basic level of skills

\footnotetext{
20 Eszter Hargittai, Survey Measures of Web-Oriented Digital Literacy, 23 Soc. ScI. COMPUTER REV. 371 (2005), available at http://www.eszter.com/research/pubs/hargittaiSSCORE05.pdf.

${ }^{21}$ Net primary enrollment is calculated by dividing the number of elementary school students by the total population of the children in that age bracket. UNITED NATIONS DEVELOPMENT GROUP, INDICATORS FOR MONITORING THE MILLENNIUM DEVELOPMENT GOALS: DEFINITIONS, RATIONALE, CONCEPTS AND SOURCES 16 (2003), http://mdgs.un.org/unsd/mdg/Resources/Attach/Indicators/HandbookEnglish.pdf. Literacy is measured as the percentage of the population fifteen years and older who can, with understanding, both read and write a short, simple statement on everyday life. Id. at 22. The United Nations' Human Development Index measures educational achievement by placing a two-thirds weight on the level of adult literacy, and a one-thirds weight on combined enrollment rates.
} 
captured by these indicators is of almost no use in securing access to knowledge. A barely literate individual with only a primary education cannot be expected to use print media or the Internet to meet their knowledge needs. To effectively participate in the knowledge society, individuals need much more than a primary education and basic literacy.

Secondary and tertiary enrollment and completion levels are more relevant proxies for the level of informational literacy, which substantially expands an individual's effective access to knowledge. Secondary education is where most individuals acquire the print literacy and complex thinking skills needed to utilize knowledge resources, such as books, print media, and most materials on the Internet. Tertiary education, in turn, is the stage where most individuals move from being primarily knowledge consumers, to acquiring the specialized skills needed to refine, produce, and share new knowledge. Educational attainment at these levels, therefore, is a useful proxy for establishing the percentage of the population with the level of informational literacy needed to meet their own needs and to contribute to broader knowledge production and diffusion. ${ }^{22}$

\section{SUMMARY}

The first component of access to knowledge is informational literacy-the ability to effectively locate, understand, apply, and communicate stored information. Further research is needed to develop accurate and cost-effective ways of assessing these skills. Until such tools are developed, the $\mathrm{A} 2 \mathrm{~K}$ index should rely on indicators of secondary and higher education completion as proxies for informational literacy.

\section{ACCESS TO THE GLOBAL KNOWLEDGE COMmoNS}

Much of human knowledge is still proprietary, stored in private databases or encapsulated in knowledge-embedded goods, which can only be accessed by paying a fee. In contrast, commons-based knowledge is in theory freely available, without the need to pay or negotiate for access. Just because knowledge or information exists in

\footnotetext{
${ }^{22}$ This second data point is also suggestive of the amount of locally-relevant knowledge being produced in a society since tertiary institutions are where most research is produced that specifically addresses national or regional economic, social, health, agricultural and environmental priorities. The size of the university student body thus has implications for the rest of the population's access to locally-relevant knowledge.
} 
the public domain, however, does not mean that everyone has access to it. Individuals still need a means of accessing the knowledge commons. This can occur either directly, as when an individual uses a library or the Internet to access knowledge, or indirectly through the assistance of a community educator, health professional, or other expert. Though many factors play a role in shaping individual access to the global knowledge commons, the $\mathrm{A} 2 \mathrm{~K}$ index should focus on the two most important: Internet access and linguistic fluency.

\section{A. INTERNET ACCESS}

The decision to treat Internet access as one of the most important A2K indicators requires some justification. In many parts of the world, Internet access still comprises a relatively insignificant mode of accessing information. The number of Internet users worldwide doubled between 2002 and 2007 , but remains at only $17.2 \%$ of the global population; regional figures range from $69.7 \%$ in North America to $3.6 \%$ in Africa. ${ }^{23}$ In the face of these statistics, an emphasis on Internet access arguably reflects a developed-world bias out of touch with the realities of the majority world, where access to knowledge still predominantly occurs through newspapers, broadcast media, and word of mouth. Despite these very real concerns, I argue that Internet access is worth privileging in the A2K index because it is qualitatively and quantitatively distinct from other ways of accessing information.

First, Internet access enhances the reach and efficiency of traditional forms of knowledge transmission. While a doctor can reach only a limited number of patients through personal consultation, she can educate thousands via the Internet, with a much smaller investment of her time. Mass media such as radio, newspapers, and magazines, can also be distributed beyond the boundaries of their traditional broadcast range or physical distribution chains. Where access to the ancient Great Library of Alexandria was physically out of reach for most of the world's denizens, the digital collections of the modern Bibliotheca Alexandrina can be accessed instantly from anywhere. ${ }^{24}$ The Internet

\footnotetext{
23 Internet World Stats, Internet Growth Statistics,

http://www.internetworldstats.com/emarketing.htm (last visited Apr. 4, 2008); Internet World Stats, Internet Usage Statistics, http://www.internetworldstats.com/stats.htm (last visited Apr. 4, 2008). Internet World Stats' data is drawn from Nielsen//Net Ratings, the International Telecommunications Union, and local national informatics centers.
}

24 The Bibliotheca Alexandria, http://www.bibalex.org (last visited Apr. 4, 2008). 
serves as an all-purpose data distribution network, capable of transmitting any traditional medium-phone conversations, radio broadcasts, newspaper articles, television and movies-while overcoming traditional limits of time and distance.

Second, unlike traditional forms of knowledge transmission, knowledge on the Internet is available on demand. Broadcast media and periodicals offer only a limited selection of information to choose from at any one time, but the interactive nature of the Internet allows individuals to access the information they want, when they want it. The Internet can thus offer access to a much broader range of knowledge and information than any conventional library, personal knowledge network, or print publication. Sophisticated digital archiving, searching, and translation tools further enhance the advantage of new media, by enabling individuals to sort through vast amounts of information quickly.

Third, the Internet uniquely offers the possibility for large numbers of people not only to access knowledge for consumption, but also to contribute to its production. Few people will ever have the opportunity to publish a book; the labor and production costs are simply too high. A much larger number of people, however, can contribute to the global knowledge commons through the Internet. This might take the form of editing a Wikipedia entry, sharing one's personal experiences or political views on a community discussion board, or answering a question on a knowledge-exchange site such as Naver.com. ${ }^{25}$ Again, the ability of Internet-based media to archive these contributions, with searchability and anytime access, means the accumulated knowledge contributions can also reach a wider audience, compared to traditional publication.

Even individuals who do not themselves have the skills or technology to directly access the Internet benefit from the greater diffusion of Internet access in their communities. Local knowledge elites-such as the village school teacher, health professionals, high school students, and non-governmental organization leaders-can use the Internet to access locally relevant knowledge and information and then share it with other community members. This dynamic also works in reverse, as when an indigenous community's political manifesto is posted online by a single Internet-savvy member or sympathizer. Thus an Internet access rate as low as $5-10 \%$ may

\footnotetext{
${ }^{25}$ See generally Choe Sang-Hun, To Outdo Google, Naver Taps into Korea's Collective Wisdom, INT'L HERALD TRIBUNE, July 4, 2007, http://www.iht.com/articles/2007/ 07/04/technology/naver.php.
} 
greatly alter the dynamics of knowledge transmission, even within communities primarily reliant on face-to-face communication.

There is one final reason not to be too concerned that a focus on Internet access is too narrow in a world where Internet access is still the privilege of a small minority: that world is rapidly changing. If the number of Internet users continues to grow at its current pacedoubling every five years-fully $70 \%$ of the world's population will be connected by 2017. Technological breakthroughs and transformative business models may accelerate that pace, for example by expanding Internet access through mobile phones, which are much more widely distributed in the developing world than computers. ${ }^{26}$ Universal Internet access-at least of a basic sort-may soon be as realistic a goal as universal access to education, clean water, or health care.

Given that Internet access deserves a special place in the A2K index, what is the best way to measure it? Working from data collected by the International Telecommunications Union (ITU), ${ }^{27}$ a number of organizations have developed composite indices to measure different aspects of information technology access. ${ }^{28} \mathrm{~A}$ consortium of United Nations agencies has recently converged around the Digital Opportunity Index (DOI) methodology, which draws on eleven indicators reflecting both the supply-side and uptake aspects of Internet access. ${ }^{29}$ The Networked Readiness Index (NRI) offers the

\footnotetext{
${ }^{26}$ See generally INT'L TELECOMM. UNION, ITU INTERNET REPORTS: THE PORTABLE INTERNET (2004), http://www.itu.int/osg/spu/publications/portableinternet/index.html (discussing the potential of Internet access through mobile technology to bridge the digital divide).

27 For a full list of available indicators, with definitions, see ITU, Telecommunications Indicators Handbook, http://www.itu.int/ITU-D/ict/publications/world/material/ handbook.html (last visited Apr. 4, 2008).

${ }^{28}$ See, e.g., INT'L TELECOMM. UNION, ITU WORLD TELECOMMUNICATIONS DEVELOPMENT REPORT: ACCESS INDICATORS FOR THE INFORMATION SOCIETY (2003), http://www.itu.int/wsis/tunis/newsroom/stats/WorldTelecomDevelopmentReport2003_E.pdf; UNCTAD, INFORMATION AND COMMUNICATION TECHNOLOGY INDICES (2003), http://www.unctad.org/en/docs/iteipc20031_en.pdf; UNCTAD, THE DIGITAL DIVIDE: ICT DEVELOPMENT INDICES (2004), http://www.unctad.org/Templates/webflyer.asp?docid= 5878\&intItemID=1397\&lang=1; UNCTAD, THE DIGITAL DIVIDE REPORT: ICT DIFFUSION INDEX (2005), http://www.unctad.org/Templates/webflyer.asp?docid= 6994\&intItemID $=1397$ \&lang $=1$.
}

29 The DOI, developed by the Partnership on Measuring ICT for Development, was first presented at the second World Summit on the Information Society in June 2005; full updates were published in 2006 and 2007. ITU \& UNCTAD, WORLD INFORMATION SOCIETY REPORT 2007: BEYOND WSIS (2007), http://www.itu.int/osg/spu/publications/ worldinformationsociety/2007/WISR07_full-free.pdf. 
most sophisticated analysis of the numerous factors driving Internet accessibility in various countries, from regulatory profile to affordability of bandwidth to educational quality. ${ }^{30}$ In contrast, the World Bank's Knowledge Index (KI) has the advantage of simplicity. Its measure of Information and Communication Technology tracks just three data points: (1) telephones per 1,000 people, (2) computers per 1,000 people, and (3) Internet users per 10,000 people. ${ }^{1}$

Given the wide variety of approaches described above, what is the best way to measure Internet access for the purposes of the A2K index? Rather than counting physical infrastructure or tracking prices, I argue for a focus on actual Internet usage as the ultimate measure of access. The inclusion in other indices of extensive data on infrastructure availability, cost, and literacy offers important perspective on why Internet usage rates are high or low in particular countries. For our purposes, however, the central issue of whether people have access to the Internet-based global knowledge commons or not is most directly answered by the number of Internet users.

For this, the best data currently available is the ITU's estimated number of Internet users relative to population. Although this indicator has the advantage of already being collected and available in internationally comparable form, it also has some drawbacks. The estimated number of Internet users does not shed light on how frequently the counted users go online, nor the quality of their Internet access (high-speed connection, privacy of the venue, etc.). Moreover, as the term "estimated number of Internet users" suggests, the ITU's data is based on imperfect estimation techniques. Worse yet, the methods of estimation are currently not consistent across countries, risking data biases.

These data quality problems can be overcome. The most accurate way to assess Internet usage rates is through a statistically representative survey. Such surveys are already regularly conducted

\footnotetext{
30 See WORLD ECONOMIC FORUM, THE GLOBal INFORMATION TECHNOLOGY REPORT 20012002: READINESS FOR THE NETWORKED WORLD; WORLD ECONOMIC FORUM, THE GLOBAL INFORMATION TECHNOLOGY REPORT 2003-2004: TOWARDS AN EQUTTABLE INFORMATION SOCIETY (executive summary available at http://www.weforum.org/pdf/ Global_Competitiveness_Reports/Reports/gitr_2006/summary.pdf); WORLD ECONOMIC FORUM, THE GLOBAL INFORMATION TECHNOLOGY REPORT 2005-2006: CONNECTING TO THE NETWORKED ECONOMY (executive summary available at http://www.weforum.org/ pdf/gitr/summary2007.pdf). The Global Information Technology Report is a collaborative project of Harvard's Center for International Development (CID) and the World Economic Forum (WEF).
}

31 World Bank, supra note 15. 
in several countries by Nielsen//NetRatings. A2K researchers should extend the reach of these survey efforts, either in partnership with the institutions that already use such data or as part of a broader A2K survey instrument. This will yield accurate, cross-nationally comparable data on Internet usage. Conducting such a survey would also provide an opportunity to capture other important data, including information on digital divides, such as gender disparities in Internet access. ${ }^{2}$ Until that time, the A2K index will need to rely on ITU estimates.

\section{B. LINGUISTIC FLUENCY}

The mere ability to access information stored in the global knowledge commons does not guarantee that an individual will be able to understand it. Virtually all stored knowledge is linguistically encoded, usually in text form. ${ }^{33}$ Individuals only have effective access to knowledge that is encoded in languages they understand. Unfortunately, not all languages are equal when it comes to providing access to knowledge. Some languages, such as English and Chinese, offer access to immense bodies of printed literature and online content. Others, such as Estonian and Quechua, offer access to distinctly smaller bodies of stored knowledge.

At the individual level, language skills powerfully shape a person's ability to access the global knowledge commons. The distribution of linguistic skills within a society can also have an indirect impact. If the most educated fifth of the Estonian population is also literate in English and French, that segment of the population will be able to access the most current ideas in science, medicine, industry, agriculture, and politics from abroad-and to adapt and translate this

\footnotetext{
32 Unfortunately, few countries currently collect data on Internet usage by sex. MICHAEL MINGES, GENDER AND ICT STATISTICS (2002), http://www.itu.int/ITUD/ict/WICTO2/doc/ pdf/Doc07_E.pdf (presented to the 3rd World Telecommunication/ICT Indicators Meeting, in Geneva, on January 15-17, 2003). Data on Internet usage by sex is available, however, for those countries where Nielsen//NetRatings performs surveys. See INT'L TELECOMM. UNION, FEMALE INTERNET USERS AS A PERCENT OF TOTAL INTERNET USERS (2002) http://www.itu.int/ITU-D/ict/statistics/at_glance/f_inet.html.
}

33 Some knowledge can be transmitted through non-linguistic representations, including pictorial representation. For example, an online video could demonstrate how to use a certain technology. Understanding the verbal explanations accompanying the video would be greatly helpful, but might not be strictly necessary. It should be safe to say, however, that very little of the world's stored knowledge currently exists in such formats. Nontextual formats also require much greater bandwidth for transmission, greatly limiting their relevance in most parts of the world, at least for the near future. 
information in ways that make it accessible to their monolingual countrymen. An example of such a society is Sweden, where Swedish -a language spoken by less than ten million people worldwide remains the dominant language of daily life, government, and the media. Because so many Swedes are also literate in English as well as French or German, even monolingual Swedes enjoy the benefits of strong national ties to the global knowledge commons, such as cutting-edge medical, agricultural, and industrial science.

Due to the important role that linguistic fluency plays in mediating access to knowledge, and the susceptibility of this factor to government intervention, it is an important factor for the A2K index to track. The question of which languages "count" for the purposes of access to knowledge, however, is a complex one. The United Nations recognizes seven languages as having international status: Arabic, Chinese, English, French, Portuguese, Russian, and Spanish. The political importance of a language, however, may not necessarily correlate with the amount of information and knowledge accessible through it. A better approach is to rely on objective data to weight each language's value in providing access to knowledge.

Counts of existing texts in print and web pages available in the language can serve as useful indicators of the stock of knowledge currently accessible in that language. Complementing this measure with counts of speakers participating in the language community adds an indicator of the potential for future expansion.34 Unfortunately, this data is not currently available, and would take significant effort to collect and verify. 35

A much simpler alternative would be to rely on related data that are readily available: the number of articles in a language community's Wikipedia. As of late 2007, Wikipedia featured over two million articles in English and over half a million articles in each

\footnotetext{
34 Some languages that perform strongly along one indicator will perform poorly in the other. Arabic and Spanish are among the top five most-spoken languages, but this potential has, so far, been poorly translated into Internet authorship. In contrast, Korean and Italian are spoken by far fewer people, but government efforts to promote universal literacy and Internet access have resulted in a wealth of online materials.

35 For an example of statistical sampling of the web to determine relative language representation, see Edward T. O'Neill et al., Trends in the Evolution of the Public Web: 1998-2002, D. LIB. MAGAZINE, Apr. 2003, http://www.dlib.org/dlib/aprilo3/lavoie/ o4lavoie.html. See also Robert Ackland \& Joseph Antony, Developing e-Research Tools for the Analysis of Large-Scale Web Crawl Data, (unpublished manuscript available at http://ess.si.umich.edu/papers/paper132.pdf) (assessing the size of print bodies of knowledge in different languages is a similarly complex, but not impossible, data collection task).
} 
German and French, but fewer than 300,000 articles in Spanish and less than 45,000 in Arabic. ${ }^{36}$ These figures are highly suggestive of the linguistic distribution of online materials. By necessity, however, they represent a very limited segment of the total body of knowledge available to a language's speakers. Researchers should therefore use this method of estimation with caution, and only until more complete data can be compiled. For the short term, however, countries may be scored according to the percentage of its population that speaks each language,37 weighted by its presence within Wikipedia, as an indication of how far this language takes its speakers in gaining access to the global knowledge commons.

\section{SUMMARY}

The second key component of access to knowledge is access to stored knowledge and information-mediated fundamentally by internet access and linguistic fluency. Internet access may be measured by ITU estimates of internet use; over time international surveys could offer more accurate data. Linguistic fluency presents an even more challenging case for measurement, requiring some assessment of different languages' relative utility for accessing the global knowledge commons. I suggest employing counts of Wikipedia articles in each language as a simple indicator, until more sophisticated measures can be developed and tested.

\section{ACCESS TO KNOWLEDGE GOODS}

The previous sections focused on access to knowledge in its abstract form as linguistically encoded information to be intellectually processed. But knowledge is not always accessed through books and broadcasts. Individuals can also benefit from access to knowledge in concrete form, as when they are able to use genetically-improved

\footnotetext{
${ }^{36}$ Meta-Wiki, List of Wikipedias, http://meta.wikimedia.org/wiki/List_of_Wikipedias (last visited Apr. 4, 2008). Placing this in terms of number of Wikipedia articles per speaker, the ratios are approximately: 1:80,00o for Zulu, 1:600o for Chinese and Amharic, 1:500o for Arabic, 1:1000 for Spanish, 1:500 for Portuguese, and 1:150 for English. These numbers are based on Wikipedia article counts, and Ethnologue counts of native speakers. Id.; Wikipedia, List of Languages by Number of Native Speakers, http://en.wikipedia.org/ wiki/List_of_languages_by_number_of_native_speakers\#Top_2o (last visited Apr. 4, 2008).
}

${ }^{37}$ Credit should be given for both native and secondary languages spoken; thus the sum of percentages speaking each language will be greater than $100 \%$. 
seeds, modern pharmaceuticals, or cell phones. Unlike linguisticallyencoded knowledge, which can be reproduced and shared at minimal cost; commodified knowledge requires a significant input of resources to produce and distribute each seed, pill, or unit. Access to these forms of knowledge is determined by the individual good's market price and the individual consumer's ability to pay that price.

Following the conceptual framework proposed by Yochai Benkler, these items can be classified as information-embedded goods and information-embedded tools. ${ }^{8}$ Information-embedded goods are those goods that are "better, more plentiful or cheaper because of some technological advance embedded in them or associated with their production," such as medicines, movies, and improved crop seeds. 39 Information-embedded goods range from those essential to human survival, to the potentially trivial. All video recordings are information-embedded goods-because of the technological processes involved in producing them-whether they are informational or not. Information-embedded tools, in turn, are those technologies necessary for research, innovation, and communication of knowledge. Examples here include books, computers, and scientific research equipment.

Access to both types of goods plays an important role in mediating access to knowledge, but for different reasons. Information tools constitute an important input to innovation and accessibility of knowledge; if these are difficult to obtain in the market, the rate of knowledge diffusion and development will slow. Access to information-embedded goods, in contrast, reflects the extent to which the consumers are able to benefit from developments and improvements in human knowledge. In practice, however, it is difficult to measure these two aspects of access separately, because information-embedded tools are actually a subset of informationembedded goods. For example, a cell phone is an information tool because you can use it to find the price of cotton, obtain medical advice, or give directions. It is also an information-embedded good because its functioning depends on innovations in microchip technology, electronics manufacturing, and software.

\footnotetext{
${ }^{38}$ These concepts are drawn from Benkler's four-part conceptual categorization, including: knowledge, information, information-embedded tools, and information-embedded goods. See BENKLER, supra note 8, at 230-33 .

39 BENKLER, supra note 8, at 230.
} 


\section{A. AFFORDABILITY OF KNOWLEDGE GOODS}

To evaluate a country's progress in making knowledge goods accessible to its population, the A2K index should track the cost of a "basket" of these goods, a methodology widely used to generate consumer price indices. Researchers first design a hypothetical shopping cart or "basket" of representative goods to be measured. The costs are summed and the result is tracked over time to assess shifts in the cost of living. The same approach could be applied to a basket of knowledge goods. The cost of the basket from country to country will reflect some variables over which countries have no control, such as higher transportation costs due to geographic isolation. However, the basket price will also be influenced by important government policies, such as taxes and tariffs, intellectual property and licensing regimes, the general state of economic competition, and subsidies for innovation. Reductions in the cost of the basket can be achieved by eliminating taxes and tariffs on knowledge goods, widening competition in production and distribution, and effectively diffusing new innovations.

Until an appropriate knowledge goods basket can be designed, tested, and implemented, there is another set of data already in existence, which may serve as a useful proxy. The Millennium Development Goals (MDG) project has developed a simple indicator for monitoring access to modern medicines. 40 Under this system, medical experts in each country report approximately what percentage of the population has effective access to the medicines on the World Health Organization's List of Essential Drugs: less than 50\%; between 50-80\%; 80-95\%; or above 95\%.41 This methodology suggests a simplified alternative to assessing the affordability of knowledge goods. Rather than pricing a basket of knowledge goods, in-country experts could simply estimate the proportion of the population that has access to each item. This approach yields less detailed information than the basket pricing approach, but would be much less expensive to implement.

\footnotetext{
$4^{\circ}$ Essential Drugs are defined as those necessary to satisfy the priority health care needs of a population. WORLD HEALTH ORGANIZATION, ESSENTIAL MEDICINES: DEFINITION AND CONCEPT, http://www.who.int/medicines/services/essmedicines_def/en/index.html (last visited Apr. 4, 2008)

41 UNITED NATIONS DEVELOPMENT GROUP, INDICATORS FOR MONTTORING THE MILLENNIUM DEVELOPMENT GOALS: DEFINITIONS, RATIONALE, CONCEPTS AND SOURCES, 89 (2003) http://mdgs.un.org/unsd/mdg/Resources/Attach/Indicators/HandbookEnglish.pdf.
} 


\section{B. Consumer Purchasing PoWer}

Of course, the market price of knowledge goods is not the only component of affordability; the distribution of resources necessary to purchase such goods is equally important. Austria and Armenia might both succeed in bringing the knowledge goods basket down to the same price, but their citizens will have very different levels of access to these goods as long as per capita GDP is $\$ 32,700$ in Austria and $\$ 3,900$ in Armenia.42 Attention to the cost of the knowledge goods basket in each country must be complemented by some measure of available income, such as per capita GDP. Adjusting this figure for purchasing power parity will yield the most accurate basis for comparing consumer purchasing power cross-nationally.

\section{SUMMARY}

Further research is needed to determine which knowledge goods are most important for access to knowledge and most relevant for global comparisons. A preliminary version of the A2K index, however, could employ existing data on access to medicines, cell phones, and Internet access. Per capita GDP, adjusted for purchasing power parity, should also be included as a significant determinant of access.

\section{AN ENABLINg Legal Framework}

Access to knowledge does not take place in a political vacuum; it is greatly shaped by legal regulations on knowledge sharing. The precise contours of what constitutes ideal information policy are a matter of great debate, and the index must avoid penalizing countries for political and legal measures whose contribution to access to knowledge is not well-documented. It is possible, however, to identify two issues on which substantial political and scientific consensus exists: respect for freedom of expression and a balanced intellectual

$4_{2}^{2}$ IMF, Report for Australia, http://www.imf.org/external/pubs/ft/weo/2007/o1/data/ weorept.aspx?pr. $x=90 \&$ pr. $y=4 \&$ sy $=2004 \&$ ey $=2008 \& \mathrm{scsm}=1 \& \mathrm{ssd}=1 \&$ sort $=$ country\&ds $=. \&$ $\mathrm{br}=1 \& \mathrm{c}=122 \& \mathrm{~s}=$ NGDPRPC\%2CNGDPPC\%2CNGDPDPC\%2CPPPPC\&grp=0\&a (last visited Apr. 4, 2008); IMF, Report for Armenia, http://www.imf.org/external/pubs/ft/weo/2007/ $01 /$ data $/$ weorept.aspx?sy $=2004 \&$ \&ey $=2008 \&$ scsm $=1 \& s s d=1 \&$ sort $=$ country\&ds $=. \& b r=1 \& \mathrm{pr} 1$ $. x=75 \& \mathrm{pr} 1 . y=4 \& \mathrm{c}=911 \& s=\mathrm{NGDPRPC} \% 2 \mathrm{CNGDPPC} \% 2 \mathrm{CNGDPDPC} \% 2 \mathrm{CPPPPC} \& \mathrm{grp}=0 \& \mathrm{a}$ (last visited Apr. 4, 2008). Data are for per-capita GDP, based on purchasing power parity in current international dollars for Austria; the figures are from 2004, the most recent year for which Armenian data is available, and are rounded to two significant digits. 
property regime. The A2K index should monitor both these issues, paying particular attention not just to what the law says on paper, but to how it works in practice.

\section{A. RESPECT FOR FREEDOM OF EXPRESSION}

The first element of a nation's legal framework that is widely identified as important in promoting access to knowledge is protection for freedom of expression.43 According to Article 19 of the Universal Declaration of Human Rights, the right to freedom of expression includes "freedom to hold opinions without interference and to seek, receive and impart information and ideas through any media and regardless of frontiers." The importance of this right to $\mathrm{A} 2 \mathrm{~K}$ is selfevident: freedom of expression protects the ability to communicate existing knowledge to new parties and enables collaboration for the development of new knowledge.

Because freedom of expression has long been accepted as important to human welfare within the paradigm of human rights, there are already several useful sources of cross-nationally comparable data upon which the A2K index can draw. The three sources of data most frequently cited in social scientific literature on human rights are the annual global human rights reports produced by Amnesty International,44 Human Rights Watch,45 and the U.S. Department of State. ${ }^{66}$ Although all three of these institutions publish their reports in narrative form only, researchers have developed various techniques to translate this information into numerical data. 47 Unfortunately, the resulting indices typically lump together various types of human rights violations, and/or focus only on extreme violations, such as disappearances and torture.

43 See, e.g., UNESCO, TOWARDS KNOWLEDGE SOCIETIES, supra note 3, at 38-43 (identifying freedom of expression as the touchstone of the knowledge society).

44 See, e.g., AMNESTY INTERNATIONAL, REPORT 2007: THE STATE OF THE WORLD's RIGHTS (2007), http://thereport.amnesty.org/eng/Homepage.

45 See, e.g., HUMAN RIGHTS WATCH, WORLD REPORT 2007 (2007), http://hrw.org/wr2k7.

${ }^{46}$ See, e.g., U.S. DEPT. OF STATE, 2006 COUNTRY REPORTS ON HUMAN RIGHTS PRACTICES (2007), http://www.state.gov/g/drl/rls/hrrpt/2006/.

47 These efforts include the Observer Human Rights Index, http://www.guardian.co.uk/rightsindex/o,201749,00.html (last visited Apr. 4, 2008); and, notably, the Maplecroft Human Rights Index, http://maps.maplecroft.com/loadmap?template=map\&issueID=56 (last visited Apr. 4, 2008) (providing normalized scores for 194 countries). 
The Freedom House Comparative Survey of Freedom offers an indexing measure more specifically focused on freedom of expression. This annual assessment of "civil liberties" in 192 countries, including "freedom of expression, assembly, association, education, and religion," comes closer to A2K's target set of concerns. $4^{8}$ Importantly, the Freedom House survey looks not to formal characteristics such as whether a nation's constitution guarantees freedom of expression or whether the nation has signed international agreements to protect freedom of expression, but rather to the actual conditions prevailing in a country. 49 This is probably the best data set upon which early versions of the A2K index may rely. ${ }^{\circ}$

\begin{abstract}
${ }^{48}$ See Freedom House, http://www.freedomhouse.org/template.cfm?page=35\&year=2005 (last visited Apr. 4, 2008) (explaining the methodology used to create the index). For the category of civil liberties, countries are awarded up to sixty points based on expert answers to fifteen questions in the categories "freedom of expression and belief," "associational and organizational rights," "rule of law," and "personal autonomy and individual rights." Points are not awarded on the basis of what rights a country's legal system promises on paper, but on the extent to which the freedoms are actually enjoyed in practice. The 0-60 score is then reduced to a scale of 1-7 for publication; to achieve greater sensitivity of measurement, the A2K index should use the underlying subscores. See Freedom House, Freedom in the World 2007 Subscores, http://www.freedomhouse.org/template.cfm?page $=372$ (last visited Apr. 4, 2008). It may also be desirable to use only the most relevant categories of "freedom of expression and belief" and "associational and organizational rights," while excluding the less-relevant "rule of law" and "personal autonomy" subscores.
\end{abstract}

49 Freedom House, Freedom in the World 2007 Subscores, supra note 48.

${ }^{50}$ The Freedom House methodology has, however, been subject to a number of criticisms for its subjectivity and an alleged political bias toward American allies. See, e.g., Kenneth A. Bollen, Political Rights and Political Liberties in Nations: An Evaluation of Human Rights Measures, 1950 to 1984, in HUMAN RIGHTS AND STATISTICS: GETTING THE RECORD STRAIGHT, 188 (Thomas B. Jardine \& Pierre P. Claude, eds., 1992), http://books.google.com/books?id=yMABbuKyNgwC; Christopher Mitchell et al., State Terrorism: Issues of Concept and Measurement, in GOVERNMENT VIOLENCE AND REPRESSION: AN AGENDA FOR RESEARCH 1, 20 (Michael Stohl \& George A. Lopez, eds., 1986). The charge of subjectivity has merit, as the country scores are based upon expert assessments rather than hard data. This is, however, inevitable in any attempt to judge a legal system, as civil liberty is not something that can be objectively counted like educational achievement or Internet access. Use of expert assessments to capture hard-tocount phenomena of governance is a widely accepted scientific methodology. See, e.g., DANIEL KAUFMANN ET AL., WORLD BANK, MEASURING GOVERNANCE USING CROSS-COUNTRY PERCEPTIONS DATA (2005), http://siteresources.worldbank.org/INTWBIGOVANTCOR/ Resources/MeasuringGovernancewithPerceptionsData.pdf (examining the reliability of perception-based data versus objective data sources as a basis for World Bank governance indicators). The charge of political bias in the rankings is more concerning; however, the evidence for such allegations seems to be only anecdotal. Additionally, excluding subscores in the category of "personal autonomy and individual rights," as discussed in note 43, would yield a modified freedom of expression score not influenced by a country's 
A2K advocates should not stop here, however. None of the existing measurement tools capture certain elements of the right to freedom of expression that are particularly important from the perspective of access to knowledge. For example, freedom of expression in the context of $\mathrm{A} 2 \mathrm{~K}$ requires particular emphasis on the subsidiary principle of "freedom of information ... the right to access data held by public authorities and to receive regular information on the initiatives taken by public authorities." ${ }_{51}$ Another aspect of freedom of expression that may be important from the $\mathrm{A} 2 \mathrm{~K}$ perspective is the role of foreign visitors and student policies in promoting the international exchange of ideas and learning. These examples suggest that while a first-generation A2K index might rely on existing measures of freedom of expression, it is worth developing additional measures that are more sensitive to access to knowledge issues.

\section{B. A Balanced Intellectual Property Regime}

In addition to the central role of freedom of expression, knowledge policy experts also agree on the need for a "balanced" intellectual property regime. $5^{2}$ Defining precisely what constitutes a balanced intellectual property regime, however, is a matter on which substantially less consensus exists. At a minimum, it is possible to say that a "balanced" intellectual property regime is one that takes into consideration both the need to recognize and protect intellectual property in order to promote innovation, as well as the need for limits on intellectual property to promote other public interests.

capitalist/socialist orientation to economic rights. This should reduce or eliminate the index's perceived bias in favor of U.S. allies.

${ }^{51}$ UNESCO, TOWARDS KNOWLEDGE SOCIETIES, supra note 3, at 39. See generally TOBY MENDEL, FREEDOM OF INFORMATION: A COMPARATIVE LEGAL SURVEY (2003), http://portal.unesco.org/ci/en/file_download.php/fa422efc11c9fgb15f9374a5eac31c7efree dom_info_laws.pdf; TOBY MENDEL, FREEDOM OF INFORMATION AS AN INTERNATIONALLY PROTECTED HUMAN RIGHT, http://www.article19.org/pdfs/publications/foi-as-aninternational-right.pdf.

${ }^{52}$ See, e.g., WORLD BANK, supra note 2, at 146 ("Well designed intellectual property regimes try to balance the private incentives for creation of knowledge against the social benefits from its dissemination.... [Developing countries] should negotiate internationally for intellectual property rights regimes that give adequate consideration to their urgent need to narrow the knowledge gap-while maintaining incentives for knowledge producers everywhere to continue their creative activity."). Despite this theoretical recognition, the concept of a balanced intellectual property regime does not find representation in the World Bank's Knowledge Assessment Methodology indices. 
To date there is no international data set that attempts to assess whether nations' intellectual property regimes are balanced.53 Indeed, there has been little academic research-much less an international consensus-on what the criteria for such an assessment would be. The World Intellectual Property Organization (WIPO) has issued guidelines in the form of model national IP laws; to date, however these recommendations have only addressed minimum standards for intellectual property protection. International conventions on intellectual property have similarly focused on setting policy "floors" in the form of minimum terms for intellectual property protection. 54 No particular exceptions or limitations on copyright and patent privileges are mandated; rather, such attempts at balance are up to each nation's discretion. This approach is also reflected in the intellectual property "watch list" 55 maintained by the United States Trade Representative (USTR), under which countries are only penalized for offering too little protection to intellectual property, never for offering too much.

An alternative to the USTR watch list is needed; one that defines the characteristics of a balanced intellectual property regime and fairly assesses all countries accordingly. The highly-charged international politics surrounding this issue make it difficult for international organizations to undertake this task.56 Academics and

\footnotetext{
53 The WIPO maintains the Intellectual Property Digital Library, which includes some statistics on patent applications by country. However, WIPO maintains no indicators addressing the quality of countries' intellectual property regimes. See WIPO, Intellectual Property Digital Library Data Collections, http://www.wipo.int/ipdl/en/resources/ content.jsp (last visited Apr. 4, 2008); WIPO, Industrial Property Statistics Online Directory, http://www.wipo.int/ipstats/en/links/ (last visited Apr. 4, 2008).
}

54 The 1971 Berne Convention established a minimum 50-year term of copyright; the 1995 TRIPS Agreement similarly established international floors of protection for trademarks, patents, trade secrets, and other forms of intellectual property. For a summary of TRIPS provisions, see WTO, TRIPS Overview, http://www.wto.org/english/tratop_e/trips_e/ intel2_._.htm (last visited Apr. 4, 2008).

55 The Office of the United States Trade Representative maintains an annual review of the "adequacy and effectiveness of intellectual property rights protection" in eighty-seven countries, referred to as the Special 301 Report. See, e.g., USTR, 2006 SPECIAL 301 REPORT: EXECUTIVE SUMMARY, http://www.ustr.gov/assets/Document_Library/ Reports_Publications/2006/2006_Special_301_Review/asset_upload_file473_9336.pdf. The 301 Report is a diplomatic tool designed to place attention and pressure on countries the U.S. Trade Representative believes have intellectual property practices that disadvantage American companies.

${ }^{56}$ Although WIPO collects information about national IP practices on its website, it has made no attempt to translate these descriptions into value judgments. WIPO, WIPO Index 
civil society, however, are well-situated to lead the way, giving consideration both to the need for intellectual property privileges to stimulate innovation and for some limits on those privileges to promote access. Once the terms of a balanced IP framework are established, researchers could compile detailed cross-national data on IP regime balance. 57

Until this work is completed, a provisional form of the A2K index will need to rely on proxies for assessing intellectual property regime balance. This could be accomplished by examining whether the particular state has-in a number of areas-gone beyond the (already imbalanced) international standards to accord still greater intellectual property privileges. These include: permitting patents on business methods, establishing patent terms of longer than 20 years or copyright terms of longer than 50 years, enacting data exclusivity provisions, or failing to provide for copyright exceptions..$^{8}$ These elements are not meant as the definitive standards of a balanced intellectual property regime, but indicators that a nation's IP regime has an overall bias toward over-protecting property privileges and under-protecting the public interest.

\section{SUMMARY}

Two elements of a nation's legal framework are essential to enabling access to knowledge: respect for freedom of expression, and a balanced intellectual property regime. An early version of the A2K index can draw on freedom of expression data already maintained by Freedom House, although this does not capture all aspects of expressive freedom important to A2K. Further research is required to more fully define the characteristics of IP balance; in the short term,

of Patent Systems, http://www.wipo.int/ipstats/en/resources/patent_systems.html (last visited Apr. 4, 2008). Despite the name "Index of Patent Systems," WIPO's information provides information in narrative form only, based on surveys completed by member countries. It does not contain a quantitative index or a scoring scheme.

57 Id.

${ }^{58}$ Although minimum intellectual property protections are internationally standardized and required by international law, exceptions are permitted to these standards as an optional matter of national public policy. This makes copyright exceptions a good target for cross-national comparisons. What exceptions does a country permit for research and educational purposes, for library lending, for orphan works, for digitization and indexing, for translation into less-used languages and disability-accessible formats? And are those exceptions that exist clearly defined and easy to invoke in practice? 
the A2K index should pay attention to a few key issues as proxy indicators.

\section{EFFECTIVE INNOVATION SYSTEMS}

Although innovation and access are often analyzed as separateand even conflicting - concerns, they are, in fact, intricately related. Until innovation occurs to produce new knowledge, no one can have access to it. No country can afford to neglect innovation, free-riding on knowledge imported from outside. Every country has unique challenges imposed by its geography, distribution of resources, history, and cultural factors. Local innovation, therefore, is crucial to developing geographically appropriate agricultural techniques, identifying appropriate prevention measures for endemic health problems, utilizing locally-available resources to meet the country's energy needs, publishing materials for citizens to learn from their own history, and solving the challenges of democratic governance.

Support for innovation can take a variety of forms. One aspect is promotion of the conditions necessary for market-based innovation. In this model, innovation is motivated by the prospect of recovering rents on a patent or by the desire to gain a short-term competitive advantage through discovery and implementation of a non-patented innovation. Governments may also promote innovation by offering subsidies or prizes for scientific research or by subsidizing institutions of higher education and centers of public research and development that nurture and facilitate innovation. Rather than trying to presume which innovation policies are most effective, the $\mathrm{A} 2 \mathrm{~K}$ index should focus on judging a nation's innovation systems by its achievements: the amount of innovation produced.

\section{A. Problems With EXISTING InNOvation Metrics}

Existing measures of innovation have focused on the indicators for which the most complete data currently exist: the number of patents registered and financial returns on patent licensing.59 Patent-based

59 See, e.g., World Bank, Knowledge Assessment Methodology, http://www.worldbank.org/kam (last visited Apr. 4, 2008). See also UNDP, HUMAN DEVELOPMENT REPORT 2006, at 327-30, Table 13, Technology: Diffusion and Creation. Both institutions use patent data as one measure of innovation, in addition to research and development (R\&D) expenditures as a proportion of GDP, and the proportion of the population employed in R\&D. The World Bank also tracks the number of publications in scientific and technical journals, using data provided by the National Science Foundation. 
measures, however, are highly problematic indicators of innovation, because most innovations do not get patented. Research indicates that the rate at which innovations are patented varies dramatically by industrial sector, from $8.1 \%$ in textiles to $79.2 \%$ in pharmaceuticals. ${ }^{60}$ This immense variability means that cross-national comparisons of patent applications are more likely to reflect the relative distribution of high-patenting and low-patenting industries in national economies rather than real differences in innovation. ${ }^{61}$ Even controlling for the type of industry, the rates at which firms choose to patent their innovations vary dramatically by country, making patenting a particularly poor indicator for a cross-national index.62 Moreover, patent-based indicators by definition cannot capture types of innovation for which patents are generally not awarded, such as basic science.

Tracking patents and royalties may still have some value for an index like the World Bank's Knowledge Economy Index-which seeks specifically to measure innovation's contribution to GDP-although research suggests that unpatented innovations are even more important to corporate profits. ${ }^{63}$ From the A2K perspective, however, relying on patents as an indicator of innovation is particularly

\footnotetext{
60 Anthony Arundel \& Isabelle Kabla, What Percentage of Innovations are Patented? Empirical Estimations for European Firms, 27 RESEARCH POLICY 127 (1998), available at $\mathrm{http}$ ://dx.doi.org/10.1016/S0048-7333(98)o0033-X (presenting an empirical study of innovation in European firms, finding that approximately one-third of all reported corporate innovations led to a patent application; product innovation patent propensity rates were over $50 \%$ only in five sectors: pharmaceuticals (79.2\%), chemicals (57.3\%), machinery (52.4\%), office and computing equipment (56.8\%) and precision instruments (56.4\%)). See also Paul H. Jensen \& Elizabeth Webster, Examining Biases in Measures of Firm Innovation, http://www.druid.dk/uploads/tx_picturedb/ds2005-1506.pdf (presented at DRUID conference in Copenhagen, on June 27-29, 2005) (concluding that the correlation between IP proxies and underlying corporate innovation is less than 20\%).

${ }^{61}$ See Anthony Arundel, Patents-The Viagra of Innovation Policy?: Internal Report to the Expert Group, at 5, http://www.knowledgesystems.org/e1oomty/inputs/ General_KBD_inputs/kbd_files/o10_european_community/KBE2_3.pdf (prepared as part of the project "Innovation Policy in a Knowledge-Based Economy" commissioned by the European Commission) (describing research indicating that product innovations result in a patent application at a rate of $52 \%$ within U.S. firms but only $44 \%$ for European firms; the patent application rates for process innovations are $44 \%$ in the U.S., but only $26 \%$ in Europe).
}

${ }^{62}$ Id. at 5-6 (concluding that European companies patent a lower percentage of both product and process innovations, compared to U.S. companies).

63 Id. at 6-9 (finding that most firms rate secrecy and lead-time as more important than patents to realizing competitive advantage from innovation). 
problematic. Patents likely represent the segment of innovation which holds the least value for expanding access to knowledgeinnovation whose utilization is limited by exclusive property rights. In contrast, contributions to basic science, new business models, and anything made available for free in the global knowledge commons, will not find representation in patent counts. Yet these types of innovation may have a far greater impact on access to knowledge. Counting patents also obscures the important fact that not all innovation is of equal value; a meaningful innovation indicator must capture the difference in social impact between the innovation of a new video game console and the discovery of a life-saving vaccine. Other commonly tracked innovation metrics have similar flaws. ${ }^{64}$

\section{B. DEVELOPING IMPROVED INNOVATION METRICS}

Researchers in many fields have called for new and improved innovation metrics. ${ }^{65}$ Developing new indicators for innovation, however, is a particularly urgent task for A2K researchers. Despite ample research indicating that patent application rates are a poor measure of innovation, many international institutions and national policy-makers continue to rely on this data, reinforcing the misconception that patenting is the primary incentive to innovate. It

\footnotetext{
64 Additional commonly-tracked innovation indicators relate to R\&D expenditure, employment in $R \& D$, and higher education enrollment in the area of science and engineering. The first problem with these measures is that they are all measures of inputs, not of results. While a correlation with innovation outcomes appeals to intuition, available research suggests that $R \& D$ measures have no greater correlation with actual innovation than do patent-based measures. See generally Jensen \& Webster, supra note 6o. A more recent line of research suggests looking at international trade flows in research and development services as a market signal of nations' relative strength in innovation; however, this research is still at a very early stage. FRANCISCO MORIS, SCIENCE RESOURCE STATISTICS, NATIONAL SCIENCE Foundation, TRADE IN R\&D-RELATED SERVICES: A NEW INDICATOR OF INDUSTRIAL KNOWLEDGE FLOWS (2006), http://www.nsf.gov/statistics/ infbrief/nsfo6326/nsfo6326.pdf.
}

65 The United States Department of Commerce has recently launched a special advisory committee to help it develop metrics for measuring the innovativeness of a country's economy; the committee's website is located at http://www.innovationmetrics.gov; Brian Wingfield, Measuring Innovation, ForBES.com, Feb. 23, 2007, http://www.forbes.com/ businessinthebeltway/2007/02/22/innovation-commerce-companies-biz-washingtoncx_bw_0223innovate.html (describing first meeting of the committee). See also National Science Foundation, Advancing Measures of Innovation: Knowledge Flows, Business Metrics, and Measurement Strategies, Workshop Report, NSF 07-306 (2006), http://www.nsf.gov/statistics/nsfo7306/pdf/nsfo7306.pdf (concluding that much further research will be necessary to develop reliable innovation metrics). 
is possible that prevailing intellectual property regimes-with long terms and poor quality controls-not only fail to promote, but actually inhibit innovation. Until better innovation metrics are developed, however, there will be no way to test this theory.

Although we are still quite far from a solution to this problem, I will offer a few suggestions on how researchers might approach the question. First, rather than attempting to measure the overall level of innovation in a society, it may be worthwhile to focus measurement efforts specifically on high-value innovation, with an emphasis on commons-based innovation. Conducting empirical studies in specific areas such as basic science, agriculture, or education should be methodologically simpler than attempting to capture innovation throughout a society or economy and is more likely to capture the aspects of innovation most important to human development. Second, there may be value in acknowledging that "innovation" is a soft concept. Much more like freedom of expression or quality of life than Internet access or informational literacy, innovation is difficult to capture by counting objective phenomena. Rather than measuring concrete data with only a tenuous (and possibly inverse) correlation to underlying innovation, perception surveys may be a better method. A survey approach could provide cross-nationally comparable indicators of innovativeness in both publicly-funded research centers and in private firms. ${ }^{66}$

\section{SUMMARY}

Innovation is unquestionably an important part of access to knowledge policy, but one unfortunately not yet subject to accurate measurement. Until better indicators can be developed and validated, it is better for early versions of the A2K index not to incorporate any innovation indicators, rather than rely on deeply flawed ones. The development of better innovation indicators must be a priority area for future qualitative and quantitative research.

\footnotetext{
${ }^{66}$ See, e.g., Jensen \& Webster, supra note 60, at 21-24 (describing the construction of a survey administered to corporate managers to assess their firms' innovativeness, with scores based on averaging responses to a number of questions designed to get at the same underlying issue; the methodology is quite similar to that employed by the Freedom House assessment of civil liberties).
} 


\section{CONCLUSION}

This proposal has identified a set of ten to twenty data points for assessing the state of access to knowledge in the various nations of the world. The proposed indicators reflect five key dimensions of access to knowledge, which may summarized as follows:

1. Education for Informational Literacy. Informational literacy-defined as the ability to locate, understand, apply, and communicate information-is an important determinant of access to knowledge at both the individual and societal levels. The A2K index can use existing data on secondary and tertiary enrollment as proxies for informational literacy. Future versions of the $\mathrm{A} 2 \mathrm{~K}$ index should incorporate survey tools assessing individuals' actual ability to perform basic information tasks or proxy measures demonstrated to correlate strongly to the ability to perform these tasks.

2. Access to the Global Knowledge Commons. Vast stores of knowledge are available in the public domain, yet not everyone has access to them. The two most important determinants of access to the global knowledge commons are Internet access and fluency in a "global gateway" language. International data on Internet usage are already available, although statistically representative surveys would increase the accuracy of these figures. More research is needed to better understand the role of language barriers in access to knowledge, although available data on Wikipedia production offer some useful insights.

3. Access to Knowledge Goods. In addition to knowledge stored in libraries and databases, knowledge is also exchanged in commodified form. Access to knowledge goods is influenced by economic competition, transportation structures, the distribution of wealth, as well as taxes and tariffs. The A2K index can draw on existing data on the affordability of medicines, cell phones, and Internet service, as well as per-capita GDP, adjusted for purchasing power parity. A more sophisticated mechanism for tracking prices through a "knowledge goods basket" would improve future versions of the $\mathrm{A} 2 \mathrm{~K}$ index. 
4. An Enabling Legal Framework. Knowledge experts agree that two areas of law are particularly important to access to knowledge: respect for freedom of expression and a balanced intellectual property regime. Legal frameworks are difficult to measure through objective data collection, but ratings based on expert assessments offer more suitable data for cross-national comparisons. The A2K index can draw upon existing ratings of freedom of expression, while working to develop an improved, A2K-specific metric. In the area of intellectual property, the pilot A2K index should focus on a small set of issues suggestive of IPR imbalance; further work is required to develop a more complete set of standards for a balanced intellectual property regime.

5. Effective Innovation Systems. Promoting access to knowledge also requires attention to innovation-how well a country promotes the development of new knowledge. Of all five dimensions of the $\mathrm{A} 2 \mathrm{~K}$ index, this is the area in which available data is least satisfactory. Existing data on patent applications and revenues fail to capture underlying innovation and contain large biases. Reliance on this data would severely distort comparisons between countries and reinforce the false impression that patenting opportunities are the primary incentive to innovation. Further research is needed to develop metrics that can better capture the dynamics of knowledge innovation.

Table 1 summarizes these five key dimensions of access to knowledge and the indicators I recommend for measuring and monitoring them. For ten of these indicators-those in bold typedata is currently available in cross-national form, permitting a pilot A2K index to be compiled within a short time-frame. For the remaining indicators-those in italics-more extensive research is required to obtain the desired data. Many desired data points-the actual number of Internet users, digital divide demographics, linguistic fluency, and access to key knowledge goods-could be obtained through an international A2K survey.

When choosing the indicators recommended here, I gave preference to measures of final outcomes, rather than inputs or intermediate outputs. To illustrate this distinction, consider the area of Internet access. My recommended indicators focus on the outcome measure of Internet users-not on the input measures of the number of computers or bandwidth available, nor on the output measures of the cost of Internet access or the percentage of villages with an 
Internet center. ${ }^{67} \mathrm{I}$ believe this results-based emphasis to be the most appropriate point for drawing international comparisons, while maintaining a relatively simple index, accessible to a broad audience. A more sophisticated A2K index may eventually be developed that also incorporates indicators of inputs and outputs, permitting more detailed analysis of policy intervention options and illuminating the dynamics affecting final outcomes. ${ }^{68}$

As a final note, while the cross-national indexing approach assumes that many factors affecting access to knowledge are determined at a national level, others are subject to strong crossborder dynamics. This is particularly true of the interrelated themes of innovation, IP regimes, and the affordability of knowledge goods. The existence of a global market means that the price of a cell phone in Kenya is largely driven by technological innovations in Korea, which in turn will be heavily influenced by intellectual property policies in Europe. Even as national governments and civil societies work to improve those dimensions of $\mathrm{A} 2 \mathrm{~K}$ within their domestic control, they also need to understand and influence policy-making at the international level to protect and promote their members' ability to access, utilize, and contribute to knowledge in a globally connected world.

\footnotetext{
67 In the area of informational literacy, I resorted to an intermediate output measureeducational attainment-because no data was available to directly assess the desired outcome; it is hoped that this output measure strongly correlates with the intended outcome. In the area of innovation systems, however, I declined to resort to the output measure of patents, because the relationship with the desired outcome-total innovation available for accessing-is at best tenuous, and may in fact be inverse.

${ }^{68}$ Such an approach is taken by the Environmental Sustainability Index, supra note 6; and the Digital Opportunity Index, supra note 29.
} 
Table 1: Indicators for Measuring and Monitoring the Five Key Dimensions of Access to Knowledge.

\begin{tabular}{|c|c|c|}
\hline Category & Area & Indicator \\
\hline \multirow[t]{4}{*}{$\begin{array}{l}\text { Education for } \\
\text { Informational Literacy }\end{array}$} & \multirow[t]{2}{*}{$\begin{array}{l}\text { Educational } \\
\text { Attainment }\end{array}$} & $\begin{array}{l}\text { Secondary education } \\
\text { indicators }\end{array}$ \\
\hline & & $\begin{array}{l}\text { Tertiary education } \\
\text { indicators }\end{array}$ \\
\hline & \multirow[t]{2}{*}{ Informational literacy } & Direct assessments of IL \\
\hline & & $\begin{array}{l}\text { Survey using proxies for } \\
\text { IL }\end{array}$ \\
\hline \multirow[t]{5}{*}{$\begin{array}{l}\text { Access to the Global } \\
\text { Knowledge Commons }\end{array}$} & \multirow[t]{2}{*}{ Linguistic fluency } & $\begin{array}{l}\text { Weighting languages } \\
\text { by Wikipedia }\end{array}$ \\
\hline & & $\begin{array}{l}\text { Better data on size of } \\
\text { knowledge stocks }\end{array}$ \\
\hline & \multirow[t]{3}{*}{ Internet Access } & $\begin{array}{l}\text { Estimated Internet } \\
\text { users }\end{array}$ \\
\hline & & $\begin{array}{l}\text { Survey of actual Internet } \\
\text { users }\end{array}$ \\
\hline & & Digital divide indicators \\
\hline \multirow[t]{5}{*}{$\begin{array}{l}\text { Access to } \\
\text { Knowledge Goods }\end{array}$} & \multirow[t]{4}{*}{$\begin{array}{l}\text { Affordability of } \\
\text { Knowledge Goods }\end{array}$} & $\begin{array}{l}\text { Access to essential } \\
\text { medicines }\end{array}$ \\
\hline & & $\begin{array}{l}\text { Cost of Internet } \\
\text { connection }\end{array}$ \\
\hline & & $\begin{array}{l}\text { Number of cell phone } \\
\text { subscribers }\end{array}$ \\
\hline & & $\begin{array}{l}\text { Cost of basket of } \\
\text { knowledge goods }\end{array}$ \\
\hline & Purchasing Power & $\begin{array}{l}\text { GDP per capita, } \\
\text { adjusted for PPP }\end{array}$ \\
\hline \multirow[t]{4}{*}{$\begin{array}{l}\text { Legal \& Policy } \\
\text { Framework }\end{array}$} & \multirow[t]{2}{*}{$\begin{array}{l}\text { Freedom of } \\
\text { Expression }\end{array}$} & $\begin{array}{l}\text { Freedom House civil } \\
\text { liberties score }\end{array}$ \\
\hline & & $\begin{array}{l}\text { A2K freedom of } \\
\text { expression score }\end{array}$ \\
\hline & \multirow[t]{2}{*}{ Balanced IP Regime } & $\begin{array}{l}\text { IP protections exceed } \\
\text { international norms }\end{array}$ \\
\hline & & $\begin{array}{l}\text { Conformance to model IP } \\
\text { policies for } A 2 K\end{array}$ \\
\hline 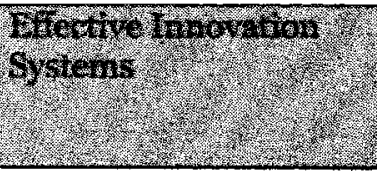 & 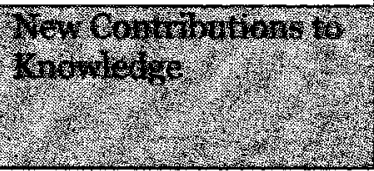 & 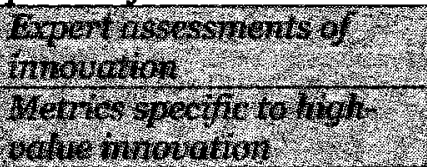 \\
\hline
\end{tabular}


